\title{
Creating Win-Win Partnerships And Adding Relevance To Educator Preparation
}

Michelle Abrego, Ed.D., University of Texas at Brownsville and Texas Southmost College, USA

Bobbette M. Morgan, Ed. D., University of Texas at Brownsville and Texas Southmost College, USA

Chuey Abrego, Ed.D., University of Texas at Brownsville and Texas Southmost College, USA

\begin{abstract}
The authors describe a partnership between two departments, in a school of education that involves educational leadership and curriculum and instruction graduate students sharing their expertise of teaching and learning with student teachers and alternatively certified teacher interns. This project provides graduate students with active participation in delivering workshops to adult learners. The beginning teachers are the participants. Beginning teachers benefit from gaining hands-on experience and research-based instructional strategies to use in their classrooms. Researchers found this activity increased the graduate students' sensitivity to the needs of beginning teachers. Over 1300 student teachers and alternative certification interns and approximately 530 graduate students have participated in the Teaching, Learning, and Service Conference. The conference is organized twice a year, on a Saturday in the fall and on a Saturday in the spring.
\end{abstract}

Keywords: adult learners, partnerships, higher education, collaboration, active learning, professional development

\section{PURPOSE}

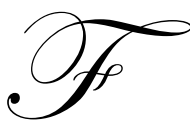

indings about the project, designed to enhance the development of graduate students at a university located along the Texas-Mexico border, are shared. The project is a collaborative effort in the School of Education between the departments of Curriculum and Instruction and School Specialties. The culminating activity is the Teaching, Learning and Service (TLS) Conference. The conference is targeted at graduate students enrolled in educational leadership courses and curriculum and instruction courses with undergraduate student teachers and alternative certification program (ACP) teacher interns as participants. The undergraduates benefit from the experience of attending a professional conference that includes an opening session, and choosing four workshops from ten offered throughout the day. Each session is evaluated by participants and graduate students receive copies of all evaluations from their presentations.

\section{PERSPECTIVES}

The impetus for the TLS Conference came from a faculty member's desire to improve her Administration of School Staff Personnel course, which is required of all students in the university's principal preparation program. The faculty member's goal was to select a meaningful assignment directly related to the work of practicing school leaders and the content of school personnel issues. Support for new teachers was the area of focus. Adult learning theory was central to the design of the project.

According to Tate, 2004 (xxii-xxvii) our adult learner students learn best when:

- $\quad$ The learning is both received and processed in more than one way (Gardner, 1983, 1999; Sternberg, 1996; Sternberg \& Grigorenko, 2000; Tate, 2003).

- $\quad$ The learning is collegial and directed at solving specific... problems (DuFour \& Eaker, 1998; Hord, 1997; Sparks \& Hirsh, 1997). 
- $\quad$ They have ample opportunity to reflect on the implementation of new competencies (Garmston \& Wellman, 1999; Sagor, 2000).

- $\quad$ Following initial training, adults are provided with ongoing support that can take the form of peer coaching or study groups (Knowles et al., 1998: Roberts \& Pruitt, 2003).

- They have input into the selection of the content and even the development of the learning experiences (Garmston \& Wellman, 1999; Little, 1993.

- The learning is connected to the vast background of knowledge and experience that the adult brings to the table (Knowles et al., 1998; Mitchell, 1998).

From their review of the research on collaborative learning in higher education, Elizabeth Barkley, Patricia Cross, and Claire Major (2005) have found abundant evidence that collaborative learning is an effective and motivating format for nontraditional students - underrepresented racial and ethnic groups, working-adult students, commuters, and re-entry students. Collaborative learning reframes the student role by requiring students to shift from a passive, privatized, and competitive learning mode to active, public, and cooperative ways of working (National Learning Communities Project, 2003).

According to the National Survey of Student Engagement (2007) socially and academically engaged adult learners are more likely to be successful in higher education. Researchers have found that improvements in instruction can contribute to increased student persistence and success (Grubb and Associates, 1999; Kuh and others, 2005). Their suggestions include more active learning, greater relevance of subject matter to students lives, and higher levels of student engagement. Best practices for adult learners in postsecondary institutions include the same three suggestions as well as inclusive learning environments, use of language of learners and their communities, and assessment of learner competence through performance outcomes (Flint, Zakos, and Frey, 2002).

The lack of administrative support for new teachers has been recognized as one of the major factors contributing to new teacher attrition (Brock 1999; Certo and Fox, 2002; Ingersoll, 2003; Norton, 1999; Shann 1998). Principals have been identified as playing a key role in supporting new teachers and supporting their induction. (Brock and Grady, 1998; Carver, 2003; Colley, 2002; Hope 1999). The conference planners sought to increase aspiring leaders' awareness of the critical role they will have in the support of new teachers.

Support for new teachers is best accomplished through high quality teacher induction programs (Wong, 2003). Preferably, those that are campus based (Johnson, et.al, 2001). However, the TLS Conference has allowed graduate students the opportunity to explore the issue of the educational leader's role in the growth and development of new teachers in a real world environment.

The TLS Conference was designed to enhance adult learning. Graduate students had an opportunity to select content and apply their own background knowledge and experiences in preparation of their presentations. They were required to work collaboratively on a job related problem - how to provide support for beginning teachers. Most graduate students worked in teams of two. Students were also asked to reflect upon their conference experience after presenting to student teachers and ACP teacher interns.

Research indicates that adults retain and apply information in meaningful ways when that information is connected to real-life experiences (Westwater \& Wolfe, 2000). Adult learning is also improved when input into the selection of the content and development of the learning experiences is permitted (Garmston \& Wellman, 1999; Little, 1993). Learning that is connected to the vast background of knowledge and experience that the adult brings into the course enhances their learning (Knowles et. al., 1998; Mitchell, 1998). Adults also learn through multiple modalities (Tate, 2004).

Adult learning is best when it is collegial and directed at the solving of specific job-related problems (DuFour \& Eaker, 1998; Hord, 1997; Sparks \& Hirsh, 1997). Ample opportunity to reflect on the implementation of new competencies supports adult learners (Garmston \& Wellman, 1999; Sagor, 2000). 


\section{PROJECT DESCRIPTION}

Beginning in Fall 2003, undergraduate student teachers and students enrolled as ACP interns were invited to attend a one-day educational conference entitled the Teaching, Learning and Service (TLS) Conference.

At the TLS Conference, student attendees (student teachers and ACP teacher interns) select and attend four one-hour conference sessions throughout the day. Sessions include topics such as: How to Conduct a Parent Conference, Reading Readiness for the Early Childhood Learner, Gifted but Special Education, Cooperative Learning in a Thematic Unit, and Classroom Management. Student attendees are asked to evaluate each of the four sessions attended and received a certificate for their attendance at the end of the conference. The conference is offered free of charge to the student teachers and ACP teacher interns.

School of Education graduate students pursuing a Master's Degree in Educational Leadership or in Curriculum and Instruction conduct the conference sessions. Graduate students work in collaborative/cooperative teams to research and develop a one-hour workshop for the TLS Conference that targets the needs of beginning teachers. Each collaborative team then has the real life experience of presenting their workshops to the student teachers and ACP teacher interns as part of the conference, a Saturday during the fall and spring semester.

An overview of the TLS Conference day is as follows: The day begins with registration and refreshments followed by an opening session in which guest speakers address the student attendees about their valuable role as educators and the need to become life-long learners. The speakers include the Dean of the School of Education, Graduate Dean, Director of Student Teaching and ACP Teacher Intern Program and professors from different School of Education departments implementing the project. Following the opening session the conference attendees go to two morning and two afternoon sessions. A catered lunch is served to all participants midday. The day ends with the awarding of certificates for attendance and collection of conference evaluations.

\section{SETTING AND PARTICIPANTS}

Research for the study was conducted in conjunction with graduate coursework and the TLS Conference. Attendance at the TLS Conference is a requirement for all student teachers and ACP teacher interns within the university's School of Education. Specific graduate course syllabi include the service requirements for participation as a presenter at the TLS Conference.

Approximately 1300 student teachers and ACP teacher interns, 550 graduate students, two program directors and three professors have participated in the conference each of the ten semesters since 2003. All ACP interns and student teachers work and live in the university's service area which includes 13 school districts. The largest district serves approximately 50,000 students and the smallest 1,500 students. Graduate student presenters come from the same region as attendees. The university has been designated as an Hispanic serving institution based on the 94\% Hispanic student population. The university is located on the United States and Mexico border.

\section{METHODS}

\section{Data Sources and Analysis}

Data on the TLS Conference Project was gathered from four semesters. Approximately 100 graduate students enrolled in three courses were asked to reflect in writing on open-ended survey questions related to their conference experience. The open-ended questions asked follow:

1) Did the presentation go as planned?

2) How beneficial was the experience of designing and presenting your presentation?

3) How did the presentation experience relate to course content?

4) What did you learn from this experience?

5) How will the experience help you as a future educational leader? 
The open-ended survey questions were analyzed using a qualitative research methodology. Researchers searched for patterns in the data concerning perspectives related to conference outcomes and then categorized the data according to the patterns that emerged (Creswell, 2003; Merriam, 1998). Multiple data sources were used to triangulate the findings and to add to the credibility of the study (Patton, 1990). Additional data sources included observations on the day of the conference, evaluations from attendees and interviews with the professor and directors involved with the project.

\section{FINDINGS}

Findings from graduate students' reflections were divided into two parts: 1.) benefits for aspiring school leaders who participated in the conference and 2.) increased awareness as to the need for school leaders to support new teachers.

\section{PARTICIPATION BENEFITS}

Graduate students identified several benefits associated with their participation in the conference. Students indicated they found the project very valuable to their overall preparation as school leaders and specific enhancement of their skills as presenters.

\section{VALUABLE EXPERIENCE FOR ASPIRING LEADERS}

Graduate students' reflections revealed that they found the TLS Conference experience very beneficial for aspiring school leaders. A student wrote, "The conference on ... was a valuable experience for me as a future administrator....The conference generated ideas and plans that I will take as a future leader". Another stated, "I think that this is a wonderful opportunity... I will add this to my resume and look forward to doing something like this again." One student discussed the fact they were grateful for the experience, "I really enjoyed the experience and I am grateful that I had an opportunity to participate in this conference." One quote from a graduate student summed it up best when she stated the following:

All in all this was a wonderful experience that has proven to me that with proper planning and preparing anything is possible. I really enjoyed this experience and look forward to presenting on topics to my teachers when I become an administrator.

Graduate students found participation in the TLS Conference to be very constructive in their preparation as educational leaders. Specific statements of their future roles as leaders were acknowledged. "As a principal, you are responsible for providing valuable and relevant training and this conference assisted me in preparing for this aspect of the job."

\section{ENHANCEMENT OF PRESENTATION SKILLS}

Surprisingly a large number of graduate students, who aspire to be school leaders, revealed that they were inexperienced presenting to a group of teachers. A large majority commented about how their self-confidence was increased by participation in the conference. They learned to be confident about speaking in front of a group as well as learning about presentation skills. One student wrote, "Speaking in public has been something that I am usually nervous about. I learned that as long as we are prepared and are familiar with the content area, it is not that difficult of a task." Another stated, "This experience was a learning experience for me as well. At first, not having presented to a group of teachers before seemed overwhelming..." Still another student wrote, "This was an excellent training tool. The other [graduate] courses should incorporate this type of assignment.... This experience has given me more confidence about myself".

Graduate student quotes further highlighted the fact that students valued learning to work as a team, and learning facilitative skills as a presenter. "I now see that it is not as easy as it looks. It is difficult to keep everyone in the audience completely attentive for the duration of the session." Another student commented: 
Many of us have never presented to a group of people they do not know. It was good for us to see how we will need to handle a question that we may not be able to answer or perhaps need to steer the discussion back on topic. We got a taste of what it is like to work on a team presentation and fully prepare the material.

Others described the learning that occurred by being required to create a presentation for the conference.

I feel that this experience will help me as an administrator because it helped give me confidence in speaking and presenting in front of peers and colleagues. It also helped me learn how to organize a presentation and how to create a presentation that was interesting and relevant to the audience that I am addressing.

\section{INCREASED SENSITIVITY FOR NEW TEACHER SUPPORT}

Graduate students acknowledged the developmental needs of new teachers. Reflections indicated awareness that beginning teachers were not "finished products" and that additional support was needed in order for new teachers to be successful in the classroom.

\section{PROFESSIONAL DEVELOPMENT}

One student wrote, "In order to help the new teachers succeed; we must invest more time in helping them learn". Another stated, "Providing staff with professional development is important in helping them [new teachers] become effective in classroom instruction". Another acknowledged, "...it [the conference] provided me with knowledge and insight as to the experiences new teachers might or might not bring to the classroom".

\section{CREATION OF COMMUNITIES OF LEARNERS}

Students' reflective writings spoke of the importance of promoting shared dialogue between new teachers and veteran teachers. "I believe that it is very important for professionals in the field to share knowledge between each other to make the district and community stronger as a whole."

Another student stated:

There seems to be a need for them [new teachers] to share and gain experience with teachers that are in the profession and to gain some wisdom. It helped me see first hand the importance of a true induction program and how it would help retain these first year teachers that do not have anyone to gain feedback from within their first years. You begin to comprehend the true meaning of a positive mentor....

\section{IMPORTANCE OF THE STUDY}

The original goal to select a meaningful assignment directly related to the work of practicing educators was fulfilled by the conference. The project aligns with the literature on how adult learning is best supported by a meaningful connection to real world experiences.

The conference also serves as a partnership between departments in higher education model that could be duplicated by other schools of education interested in providing support to their educational community of student teachers, alternative certification interns, educational leadership and curriculum and instruction graduate students.

\section{AUTHOR INFORMATION}

Michelle Abrego, Ed. D., an Associate Professor, is a member of the School of Education in the School Specialties Department at The University of Texas at Brownsville and Texas Southmost College. Her research interests include professional development of educators, school leadership, and program development in higher education.

Bobbette M. Morgan, Ed. D., an Associate Professor, is a member of the School of Education in the Curriculum and Instruction Department at The University of Texas at Brownsville and Texas Southmost College. Her areas of 
interest include cooperative learning, adult learning strategies, brain-compatible learning and models of teaching. She currently serves as Director of the Doctoral Program.

Chuey Abrego, Ed. D., an Assistant Professor, is a member of the School of Education in the School Specialities Department at The University of Texas at Brownsville. His research interests include communities of learners, principal preparation, and community involvement.

\section{REFERENCES}

1. Brock, B.L. (1999) The principal's role in mentor programs. Mid-Western Educational Researcher, 12, (4), 1-4.

2. $\quad$ Brock, B.L. \& Grady, M.L. (1998). Beginning teacher induction programs. Clearing House, 71 (3), 178184.

3. Carver, C.L. (2003). The principal's role in new teacher induction. In M. Scherrer (Ed.), Keeping good teachers (pp. 33-41). Alexandria, VA: Association for Supervision and Curriculum Development.

4. Certo, J.L. \& Fox, J. E. (2002, October/November). Retaining quality teachers. High School Journal, 86 (1), $1-15$.

5. Colley, A. (2002, March). What can principals do about new teacher attrition? Principal Magazine, 1-3.

6. $\quad$ Creswell, J. W. (2003). Research design: Qualitative, quantitative and mixed methods approaches $\left(2^{\text {nd }}\right.$ Edition). Thousand Oaks, CA: Sage.

7. DuFour, R. \& Eaker, R. (1998). Professional learning communities at work: Best practices for enhancing student achievement. Reston, VA: Association of Supervision and Curriculum Development.

8. Gardner, H. (1983). Frames of mind: The theory of multiple intelligences. New York: Basic Books.

9. Gardner, H. (1999). Intelligence reframed: Multiple intelligences for the $21^{\text {st }}$ century. New York: Basic Books.

10. Garmston, R. \& Wellman, B. (1999). The adaptive school: A sourcebook for developing collaborative groups. Norwood, MA: Christopher-Gordon.

11. Hope, W. (1999). Principals' orientation and induction activities as factors in teacher retention. Clearing House, 73 (1), 54-56.

12. Hord, S. M. (1997). Professional learning communities: Communities of continuous inquiry and improvement. Austin, TX: Southwest Educational Development Laboratory.

13. Ingersoll, R.M. (2003). Is there really a teacher shortage? The Consortium for Policy Research in Education and the Center for the Study of Teaching and Policy. Retrieved February 25, 2008, from http://depts.washington.edu/ctpmail/PDFs/Shortage-RI-09-2003.pdf

14. Johnson, S.M., Birkeland, S., Kardos, S.M., Kauffman, D.; Liu, E.: Peske, H.G. (2001). Retaining the next generation of teachers: The importance of school-based support. Harvard Education Letter Research Online. Retrieved July 22, 2005, from http://www.edletter.org/past/issues/2001-ja/support.shtml.

15. Knowles, M. S., Holton, E. F. \& Swanson, R. A. (1998). The adult learner. Houston, TX: Gulf.

16. Levine, A. (2005). Educating school leaders. Washington D.C., The Education Schools Project. Retrieved February 28, 2008, from http://www.wallacefoundation. org/

ELAN/TR/KnowledgeCategories/Developing+Leaders/PreService+Training/pre leaders.htm

17. Little, J. W. (1993, summer). Teacher's professional development in a climate of educational reform. Educational Evaluation and Policy Analysis, 15, 120-51.

18. Merriam, S. B. (1998). Qualitative research and case study applications in education. San Francisco, CA: Jossey-Bass.

19. Mitchell, G. (1998). The trainers handbook: The AMA guide to effective training (3rd ed.). New York: AMACOM.

20. Norton, M.S. (1999, Spring). Teacher retention; reducing costly teacher turnover. Contemporary Education, 70 (3), 52-56.

21. Patton, M. Q. (1990). Qualitative evaluation and research methods ( $2^{\text {nd }}$ ed.). Newbury Park, CA: Sage.

22. Roberts, S. M. \& Pruitt, E. Z. (2003). Schools as professional learning communities: Collaborative activities and strategies for professional development. Thousand Oaks, CA: Corwin Press.

23. Sagor, R. (2000). Guiding school improvement with action research. Alexandria, VA: Association for Supervision and Curriculum Development. 
24. Shann, M. H. (1998) Professional commitment and satisfaction among teachers in urban middle schools. Journal of Educational Research, 92(2), 67-74.

25. Sparks, D. \& Hirsch, S. (1997). A new vision for staff development. Alexandria, VA: Association for Supervision and Curriculum Development.

26. Sternberg, R. J. (1917). Successful intelligence: How practical and creative intelligence determine success in life. New York: First Plume.

27. Sternberg, R. J., \& Grigorenko, E. L. (2000). Teaching for successful intelligence: To increase student learning and achievement. Arlington Heights, IL: Skylight.

28. Tate, M. L. (2004). "Sit \& get" won't grow dendrites: 20 professional learning strategies that engage the adult brain. Thousand Oaks, CA: Corwin Press.

29. Westwater, A. \& Wolfe, P. (2000). The brain-compatible curriculum. Educational Leadership, 58 (3), 4952 .

30. Wong, H.K. (2003). Save millions: Train and support new teachers. School Business Affairs, 69(10), pp. $19-22$.

\section{$\underline{\text { NOTES }}$}


NOTES 